DOI: 10.20472/IAC.2019.047.024

\author{
HARRIET STRANAHAN \\ University of North Florida, United States \\ MARY BEAL \\ University of North Florida, United States \\ MARY BORG \\ University of North Florida, United States
}

\title{
AN UNFORTUNATE EFFECT OF RISING TUITION COSTS: SOARING DEBT FOR VULNERABLE STUDENTS
}

\begin{abstract}
:
The cost of college tuition has increased by over $300 \%$ since 2000 , far outpacing rising prices of virtually all other goods and services in the US, including healthcare. Unfortunately for nearly $70 \%$ of undergraduates in the US, their student loan debt has increased even faster, outpacing both rising auto and credit card debt. A student with an average loan debt of over $\$ 35,000$ typically carries this debt for more than 2 decades, is less likely to save for retirement or buy a home, and with disastrous financial consequences fully $25 \%$ default on their student loans. Significant media attention has highlighted the magnitude and some of the consequences of rising student debt, yet we know little about the characteristics that make students vulnerable to accumulating so much debt. This study provides new information about the characteristics and circumstances of students at risk for high loan debt. We estimate a selection bias corrected regression using a sample of more than 13,500 graduates from large public university in the United States. We find that the decision to take out student loans and the amount of debt accrued differs across income, ethnicity, support networks and chosen major. Interestingly, our results show new information about a billion dollar publicly funded program in Florida, Florida Bright Futures Scholarship (FBF). We find that FBF plays a key role in reducing recipient's debt burdens. Whereas previous research has shown the merit-based FBF scholarships benefit higher income households disproportionately, our results show it is the lower income households that benefit most from FBF in terms or reduced loan burdens at graduation.
\end{abstract}

\section{Keywords:}

Microeconomics, Public Finance, Student Loan Debt

JEL Classification: D00, L38 